\title{
The NGO CARE and food aid from America, 1945-80
}

'Showered with kindness'?

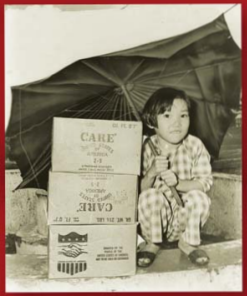

Heike Wieters 


\section{The NGO CARE and food aid from America, 1945-80}

\section{MANCHESTER 1824}

Manchester University Press 


\section{HUMANITARIANISM}

This series offers a new interdisciplinary reflection on one of the most important and yet understudied areas in history, politics and cultural practices: humanitarian aid and its responses to crises and conflicts. The series seeks to define afresh the boundaries and methodologies applied to the study of humanitarian relief and so-called 'humanitarian events'. The series includes monographs and carefully selected thematic edited collections which will cross disciplinary boundaries and bring fresh perspectives to the historical, political and cultural understanding of the rationale and impact of humanitarian relief work.

Islamic charities and Islamic humanism in troubled times Jonathan Benthall

Humanitarian aid, genocide and mass killings: Médecins Sans Frontières, the Rwandan experience, 1982-97 Jean-Hervé Bradol and Marc Le Pape

Calculating compassion: Humanity and relief in war, Britain 1870-1914 Rebecca Gill

Humanitarian intervention in the long nineteenth century

Alexis Heraclides and Ada Dialla

The military-humanitarian complex in Afghanistan

Eric James and Tim Jacoby

Donors, technical assistance and public administration in Kosovo Mary Venner 


\section{The NGO CARE and food aid from America, 1945-80}

'Showered with kindness?'

Heike Wieters

Manchester University Press 


\section{Copyright (C) Heike Wieters 2017}

The right of Heike Wieters to be identified as the author of this work has been asserted by her in accordance with the Copyright, Designs and Patents Act 1988.

Published by Manchester University Press

Altrincham Street, Manchester M1 7JA

www.manchesteruniversitypress.co.uk

British Library Cataloguing-in-Publication Data

A catalogue record for this book is available from the British Library

Library of Congress Cataloging-in-Publication Data applied for

ISBN 9781526117212 hardback

First published 2017

The publisher has no responsibility for the persistence or accuracy of URLs for any external or third-party internet websites referred to in this book, and does not guarantee that any content on such websites is, or will remain, accurate or appropriate.

Typeset by

Servis Filmsetting, Stockport, Cheshire 